International Journal of Current Advanced Research

ISSN: O: 2319-6475, ISSN: P: 2319 - 6505, Impact Factor: SJIF: 5.995

Available Online at www.journalijcar.org

Volume 6; Issue 4; April 2017; Page No. 3459-3461

DOI: http://dx.doi.org/10.24327/ijcar.2017.3461.0293

Research Article

\title{
TO ASSESS KNOWLEDGE AND AWARENESS AMONG THE DENTAL STUDENTS ABOUT THE ORAL MANIFESTATION ARISING IN HAND FOOT AND MOUTH DISEASE
}

\author{
Saranya S
}

Saveetha Dental College, Chennai, India

A R T I C L E I N F O

\section{Article History:}

Received $8^{\text {th }}$ January, 2017

Received in revised form $10^{\text {th }}$ February, 2017

Accepted 22 ${ }^{\text {nd }}$ March, 2017

Published online $28^{\text {th }}$ April, 2017

\section{Key words:}

Manifestation Arising, Hand Foot And Mouth Disease

\begin{abstract}
A B S T R A C T
Aim: To do a survey among the dental students and bring out the oral manifestation arising in hand foot and mouth diet

Background: Hand foot and mouth disease is a common viral illness Characterised by fever and vesicles in the mouth and distal extremities.It is caused by coxsackie A vita and less commonly by coxsackie B and enterovirus 71 . It usually affects children's under 10 years of age.

Materials and Methods: A survey was conducted among 100 dental students. Questionnaire survey was done. The questionnaire consists of 10 questions and it was distributed. Their answers were taken and represented in the form of pie charts.
\end{abstract}

Copyright $₫ 2017$ Saranya $\mathbf{S}$. This is an open access article distributed under the Creative Commons Attribution License, which permits unrestricted use, distribution, and reproduction in any medium, provided the original work is properly cited.

\section{INTRODUCTION}

Headfoot and mouth disease (HFMD) is caused by human enteroviruses. It is coxsackie A 16 virus. Coxsackievirus A16 was first identified next year in 1958 in Canada. HEV71 was discovered much later in 1969 in California from the stool of an infant who was suffering from non-HFMD encephalitis. Some cases are caused by a different but related virus called enterovirus 71 , more predominant in children particularly under age group of 10 years although it affects older children and the adults but its not as virulent. It highly contagious infection. The viruses that cause HFMD are spread through close personal contact, through the air from coughing, and feces of an infected person. other strains of coxsackievirus and enterovirus can also be responsible. HFMD occurs in all areas of the world. some people, particularly adults, can pass the virus with our showing any symptoms of the disease. It can occur at any time of year but is most common in the summer and fall.There's no specific treatment for hand -foot and mouth disease. you can reduce your chid's risk of infection from head foot and mouth disease by practicing good hygiene and teaching your child how to keep clean.

The typical clinical manifestations of HFMD are fever, stomatitis with oral ulcers, and an exanthem affecting the palms, soles, and other parts of the body. These last less than 7 to 10 days, usually occur during the spring to fall months, and have a benign course.

*Corresponding author: Saranya S

Saveetha Dental College, Chennai, India
The incubation period is 3 to 5 days, with a prodrome that may include fever, malaise, abdominal pain, and myalgia before the onset of oral and cutaneous findings. Painful oral ulcers may precede the exanthem and can result in dehydration.

The cutaneous manifestation of HFMD is typically a papulovesicular rash affecting the palms, soles, and buttocks. Other sites may include the knees, elbows, and the dorsal surfaces of the hands and feet. The lesions may be maculopapular and can be either asymptomatic or tender and painful. Desquamation can follow the exanthem, and lesions usually resolve without scarring or secondary infection.

\section{Laboratory testing}

In mild cases of HFMD, particularly in patients with a high probability of having the disease based on their clinical characteristics and sick contacts, laboratory testing is not necessary. Testing is usually reserved for severe cases and public health investigation of outbreaks.

Viral culture is the gold standard for diagnosing HFMD, but the final results can take nearly a week.

Polymerase chain reaction testing is faster, with a turnaround time of less than 1 day. It identifies viral RNA and is highly sensitive for detecting central nervous system infection.

Where should samples be collected? Serum viremia precedes invasion of the skin and mucous membranes, so plasma can be tested. Inside the body, enteroviruses initially replicate in the gastrointestinal tract, although collecting a rectal swab or a stool sample is somewhat invasive. Further, in an 
enterovirus 71 epidemic in Taiwan, 93\% of the patients had positive throat swabs, but only $30 \%$ tested positive by rectal swabs or analysis of the feces. ${ }^{27}$ At present, throat and vesicle specimens are considered to be the most useful sources for diagnostic purposes.

ELISAs. Newly developed IgM-capture enzyme-linked immunosorbent assays (ELISAs) for coxsackievirus A16 and enterovirus 71 appear quite promising for diagnosing HFMD. These tests are inexpensive and detect IgM antibodies early and in a high percentage of patients. In the first week of the disease, the IgM detection rate was found to be $90.2 \%$ for enterovirus 71 and $68 \%$ for coxsackievirus A16.

Cross-reactivity between these two viruses was a problem with ELISA testing in the past, causing false-positive results for enterovirus 71 in patients who in fact had coxsackievirus A16. The problem appears to be resolved in new versions that use specific enterovirus 71 proteins, eg, VP1.

\section{DISCUSSION}

Hand, foot and mouth disease is a common infection that causes mouth ulcers and spots on the hands and feet.It's most common in young children - particularly those under 10 -but can affect older children and adults as well.Hand, foot and mouth disease is contagiousness can cleared by itself with proper management and treating the symptomsThe infection can be spread by close person to person contact and contact with contaminated surfaces.The infection is caused by a number of different viruses, so it's possible to get it more than once. Most people develop immunity to these viruses as they get older.The fever can be high, but often is mild. Blisters on the hands and feet, and ulcers or blisters in the mouth appear 1-2 days after the first symptoms and may last for 2 - 7 days. The blisters often appear in the nappy (genital) area and sometimes also on the upper arms, upper legs and bottoms of children. Aseptic" (also called "viral") meningitis (rare): Symptoms of meningitis are moderate-severe headache, discomfort when bending the head forward (classically tested by trying to touch the chin to the chest), and nausea and vomiting. Meningitis is an infection of the tissues and spinal fluid that surrounds the brain and the spinal cord. The diagnosis is confirmed by a lumbar puncture (also known as a "spinal tap"). Depending upon severity of the patient's symptoms, they may need to be hospitalized.No vaccine yet exists against the EV71 virus.

\section{CONCLUSION}

Fortunately $76 \%$ dental students are aware of this disease and the virus causing it. There are no vaccine for this disease. HFMD, that was once considered a disease of cattle, has been emerging as a common human childhood disease in the last few years. The incidence of this disease increase every year. Though in most of the cases, it is nonfatal, there are some reported cases of complications seen in HFMD patients, all dentists, paediatricians and dermatologists should be aware of the clinical features of this disease and possible complications. The awareness of HFMD is good among the dental students

\section{References}

^ Mao, QY; Wang, Y; Bian, L; Xu, M; Liang, Z (May 2016). "EV71 vaccine, a new tool to control outbreaks of hand, foot and mouth disease (HFMD).". Expert review of vaccines. 15(5): 599-606. doi:10. 1586/14760584.2016.1138862. PMID 26732723

Centers for Disease Control and Prevention. Deaths among children during an outbreak of hand, foot, and mouth disease - Taiwan, Republic of China, April-July 1998. MMWR 1998; 47; 629-32. Erratum in MMWR 1998; 47;718.

Chan KP, Goh KT, Chong CY, Teo ES, Lau G, Ling AE. Epidemic hand, foot and mouth disease caused by human enterovirus 71, Singapore. Emerg Infect Dis. 2003:78-85.

Chan Y-F, AbuBakar S. Recombinant human enterovirus 71 in hand, foot and mouth disease patients. Emerg Infect Dis. 2004;10:1468-70.

Fujimoto T, Iizuka S, Enomoto M, Abe K, Yamashita K, Hanaoka $\mathrm{N}$, et al. Hand, foot, and mouth disease caused by coxsackievirus A6, Japan, 2011 [letter]. Emerg Infect Dis. 2012;18(2):337-9.

Gong LM, Ge Q, Yan JY, Lu YY, Feng Y, Mao HY, et al. Isolation and sequencing of vp1 region of enterovirus 71 strains in Zhejiang, China. Zhonghua Liu Xing Bing Xue Za Zhi 2005; 26:971-4. PubMed

Hamaguchi T, Fujisawa H, Sakai K, Okino S, Kurosaki N, Nishimura $\mathrm{Y}$, et al. Acute encephalitis caused by intrafamilial transmission of enterovirus 71 in adults. Emerg Infect Dis. 2008; 14:828-30.

Li L, He Y, Yang H, Zhu J, Xu X, Dong J, et al. Genetic characteristics of human enterovirus 71 and coxsackievirus a16 circulating from 1999 to 2004 in Shenzhen, People's Republic of China. $J$ ClinMicrobiol. 2005; 43:3835-9.

Lin SE, Zhang Q, Xie HP, Xie JP, He JX, Dong QL, et al. Phylogenetic analysis of enterovirus 71 isolated from patients with hand, foot and mouth disease in Guangdong and Fujian Provinces, 2000-2001. ZhonghuaShi Yan He Lin Chuang Bing Du Xue Za Zhi. 2004; 18:227-9.

Lin T-Y, Twu S-J, Ho M-S, Chang L-Y, Lee CY. Enterovirus 71 outbreaks, Taiwan: occurrence and recognition. Emerg Infect Dis. 2003;9.

Ooi E-E, Phoon M-C, Ishak B, Chan SH. Seroepidemiology of human enterovirus 71, Singapore. Emerg Infect Dis. 2002; 8:995-7.

Ooi MH, Wong SC, Lewthwaite P, Cardosa MJ, Soloman T. Clinical features, diagnosis, and management of enterovirus 71. Lancet Infect Dis 2011:9;10971105. DOI PubMed

Osterback R, Vuorinen T, Linna M, Susi P, Hyypiä T, Waris M. Coxsackievirus A6 and hand, foot, and mouth disease, Finland. Emerg Infect Dis. 2009; 15:1485-8.

Shieh WJ, Jung SM, Hsueh C, Kuo TT, Mounts A, Parashar $\mathrm{U}$, et al. Pathologic studies of fatal cases in outbreak of hand, foot, and mouth disease, Taiwan. Emerg Infect Dis. 2001;7:146-8.

Tu PV, Thao NT, Perera D, Huu TK, Tien NT, Thuong TC, et al. Epidemiologic and virologic investigation of 
hand, foot, and mouth disease, southern Vietnam, 2005. Emerg Infect Dis. 2007;13:1733-41.

Wu TN, Tsai SF, Li SF, Lee TF, Huang TM, Wang ML, et al. Sentinel surveillance for enterovirus 71, taiwan, 1998. Emerg Infect Dis. 1999;5:458-60.
Yang ZH, Zhu QR, Li XZ, Wang XH, Wang JS, Hu JY, et al. Detection of enterovirus 71 and coxsackievirus A16 from children with hand, foot and mouth disease in Shanghai, 2002. Zhonghua Er Ke Za Zhi 2005;43:64852.

\section{How to cite this article:}

Saranya S (2017) ' To Assess Knowledge And Awareness Among The Dental Students About The Oral Manifestation Arising In Hand Foot And Mouth Disease', International Journal of Current Advanced Research, 06(04), pp. 3459-3461.

DOI: http://dx.doi.org/10.24327/ijcar.2017.3461.0293 